DOI: $10.20472 / E F C .2017 .007 .013$

\author{
LUKAS MASLO \\ University of Economics, Prague, Czech Republic
}

\title{
A JUST PRICE: OBJECTIONS AND SUGGESTED SOLUTIONS
}

\begin{abstract}
:
This paper examines the concept of a just price not as a historical but as theoretical problem. After a detailed exposition of the scholastic theory of value, price and commutative justice, the author identifies four main subjective-value-based objections to the concept of a just price and settles them one after another. These objections are 1 ) an apparent self-contradiction consisting in stating a subjective nature of utility and, at the same time, equality of value in exchange; 2 ) how can a voluntary exchange be unjust; 3 ) how can a just price be found in an isolated exchange of a unique good; 4) a missing satisfactory definition of a just price. The author suggests to settle the first objection by identifying the ontological status of the objective value. Leaning on a distinction of an objective value in use (virtuositas) and subjective desirability (complacibilitas) made by Saint Bernardino of Sienna and Saint Antonino of Florence, the author asserts that while complacibilitas is a potentiality of subjective desirability resting in an individual, virtuositas is a potentiality of usefulness resting in a thing. On account of this, a following solution is suggested: a particular usefulness is not purely subjective because it does not depend on a subjective perception of an individual; it is a metaphysical accident of a thing, not a metaphysical accident of an individual; a particular usefulness is not purely objective, either, because it is a relation to an individua; thus, equality in exchange means equality of potentiality of usefulness which is not a particular usefulness but a set of all usefulnesses concealed in the potentiality of the thing, even though they have not yet been actuated. The author suggests to settle the second objection by providing a logical proof for the assertion that an exchange in which one party suffers an unjust price is not a voluntary exchange and, on the grounds of this, the author demonstrates that an unjust exchange cannot be a voluntary exchange. Finally, the author suggests a definition of a just price which is applicable to any exchange, whether a competitive price exists or not.
\end{abstract}

\section{Keywords:}

just price, commutative justice, value, potentiality, act, metaphysical accident, virtuositas, complacibilitas

JEL Classification: A12, B11, D46 


\section{Introduction}

In a Czechoslovak movie from the middle 1980s, there is a sequence in which a lady visits a usurer named Lón and wants to put an expensive ring in pawn. The usurer makes his bid: "Twelve hundred." The lady, in a complete shock, stutters out: "It's worth six thousand." The usurer gives her a smile and says: "Not always, not to everyone." In this concise reply, Lón the usurer has expressed what the subjective value theory is about. According to this theory, the only value which is worth discussing is the market price which is co-determined by the marginal utility of the thing to the buyer and the marginal utility of the thing to thy seller. As long as the marginal utility to the buyer exceeds the marginal utility to the seller, there is an interval in which they can come to an agreement about the price. Whatever price they agree on, as long as neither of them is forced or deceived, this price will be just because determined in a voluntary exchange. Twelve hundred which Lón the usurer offered to the lady will become a market price if the lady accepts his offer, according to the subjective value theory, and its justness or unjustness is an empty notion without a real meaning. A just price (pretium iustum) such as presented by the Catholic Church and catholic scholars (scholastics or schoolmen) is a concept which says something else, though. According to this approach, those twelve hundred is not a just price because the usurer uses the state of need in which the lady finds itself and which pushes the lady's reservation price below its normal level. However, the subjectivists would reply that there is nothing as "normal" reservation price. The seller's reservation price is simply equal to his marginal utility and marginal utility from a thing is not something constant but an ever-changing variable the value of which depends on the person's income, personal tastes and even his mood at the present moment. How do you want to find the just price in a particular exchange if the marginal utility is subjective and, on account of that, inter-personally incomparable, the proponents of the subjective value theory will ask. And they go on: not only you cannot find the just price in a particular exchange but are even unable to provide a full-fledged definition of what a just price actually is. We know now that a just price as put forward by the scholastics is nothing but a myth, the subjectivists say. And this viewpoint is shared by almost every economist nowadays. In this paper, I accept the challenge and I am going to try to prove that a just price can be both defined and found in a particular exchange.

In the second section, I will present the main arguments in favor of the existence of a just price as presented by some of the most distinguished schoolmen (Saint Thomas Aquinas, Leonardus Lessius, Juan de Lugo, Luis Molina) and, at the same time, several disturbing objections against the just price which need to be settled if the concept of a just price is to ever get rehabilitated. In the third section, I will expound the ontological notional apparatus that I will make use of to provide a philosophical foundation to the concept of a just price, leaning on the value theory of Saint Bernardino of Sienna and Saint Antonino of Florence. In the fourth section, I will settle the objections against the just price as presented in the second section, suggest a 
definition of a just price and examine its compatibility with the arguments of scholastics themselves. In the conclusion, the main insights of this paper will be summarized.

\section{A Just Price in Scholastics and A Criticism Thereof}

There has been an argument ${ }^{1}$ that the theory of a just price was based on a labor theory of value or, more generally, cost theory of value but there is a relatively common agreement among the historians of economic theories that this was rather down to some ambiguous passages in Saint Thomas' Commentary on the Aristotle's Nicomachean Ethics. One such passage examines an exchange done between a builder and a shoemaker and analyses what constitutes a commutative justice in this case:

"Therefore, if first an equality according to proportionality is found so that on one side a certain number of sandals be fixed as equal to one house (for a builder incurs more expense in building one house than a shoemaker in making one sandal), next, corresponding reciprocation is had so that the builder may receive many sandals equal to one house and the shoemaker one house, there will be recompense-as was said-made according to proportion by a diagonal conjunction." (Sententia libri ethicorum, liber V, lectio 8, n. 976)

Another one who might have given an impulse for a cost-value theory to be attributed to the concept of just price of scholastics was John Duns Scotus who, according to Schumpeter:

"at all events, may be credited with having related just price to cost, that is, the producers' or traders' expenditure of money and effort (expensae et labores)." (Schumpeter, 1954, p. 93).

It is hard to say in case of Scotus, to what extent he really was an adherent of a costvalue theory or to what extent this was just a way of approximating a just price, as might be the case as I will show later on. In any case, Saint Thomas cannot be labelled as a cost-value theory proponent with respect to other passages where he states explicitly that value is derived from utility:

"As Augustine says (De Civ. Dei xi, 16) the price of things salable does not depend on their degree of nature, since at times a horse fetches a higher price than a slave; but it depends on their usefulness to man. Hence it is not necessary for the seller or buyer to be cognizant of the hidden qualities of the thing sold, but only of such as render the thing adapted to man's use, for instance, that the horse be strong, run well and so forth. Such qualities the seller and buyer can easily discover." (Summa, II-II, questio 77 , articulus 2, ad 3).

${ }^{1}$ E. g. R. H. Tawney. (1950). Religion and the Rise of Capitalism. 
So, either Saint Thomas contradicts himself, which is hard to believe in case of a man of such a developed ability of logical thinking which Saint Thomas undoubtedly was, or the cost approach as suggested in the example of a builder and a shoemaker is a mere approximation, not an expression of the essence of a just price.

There also is a common agreement among historians of economic thought that utility was never meant to reflect any value inherent to a thing itself. Schumpeter on this:

"Molina and Lugo, for instance, were as careful as C. Menger was to be to point out that this utility was not a property of the goods themselves but or identical with any of their inherent qualities, but was the reflex of the uses the individuals under observation proposed to make of these goods and of the importance they attached to these uses." (Schumpeter, 1954, p. 98).

Similar point has been made by Dempsey (1943, p. 149) and the same opinion has been expressed by Casey (2010) and Zúñiga (2010):

"The best explanation of what Saint Thomas means by absolute equality is the mutual satisfaction obtained by each contracting party in an exchange. The Schoolmen's common acceptance of just price as the market price also reinforces the thesis of the central role of subjective (economic) valuation in Saint Thomas' account of exchange value." (Zúñiga, 2010).

As a result, the equivalence in exchange demanded by the principle of commutative justice cannot mean equivalence of utilities. Which is being confirmed by Saint Thomas himself:

"In commutative justice we consider chiefly real equality. On the other hand, in friendship based on utility we consider equality of usefulness, so that the recompense should depend on the usefulness accruing, whereas in buying it should be equal to the thing bought." (Summa, II-II, questio 77, articulus 1, ad 3).

A just price is such a price which preserves commutative justice. Commutative justice or justice in exchange, a notion originated from Aristotle and received by Saint Thomas, can be characterized by a simple rule "to render to each that which is his, according to an equality" (Dempsey, 1943, p. 135), as opposed to distributive justice or justice in distribution which means "to render to each that which is his, according to a proportionality". While commutative justice directs conduct of a person to another person, distributive justice directs conduct of a community to a person. Alternatively, Dempsey captures commutative justice like this: 
"Justice in exchange is preserved when each party receives as much as he gives and gives as much as he receives, i. e. the exchange must be according to an equality, and an equality not of weight and number but of value." (Dempsey, 1943, pp. 137-138)

For an economist suckled on the subjective value theory, this idea is ridiculous for two reasons. First, since a value is subjective, and subjective entities cannot be compared inter-personally, a value to one person can never be compared to a value of another person. Second, even if a value could be expressed somehow, requiring that a value given were equal to a value received results in a same-off utility outcome which contradicts the very meaning of any exchange which is increasing one's own utility. And because a just price is such that preserves justice in exchange, the very same criticism can be directed against a just price.

While Saint Thomas pays a relatively small attention to exchange and just price because purely economic questions were at the margin of his interest, other scholastic teachers were more specific about application of commutative justice to economics. The late scholastics, especially, attract a present-day economist's attention by the presence of a competitive market as an assumption in most of their analyses. And it is the competitive-market framework which is shaping the late-scholastic considerations about a just price. Lessius defines a just price like this:

"The just price is held to be that price that is determined either by the public authorities in consideration of the common good or by the common estimation of people." (Lessius, De lustitia, liber 2, caput XXI., dubitatio 2, [7]).

The former price mentioned in Lessius' definition is being referred to as a legal price, the latter as a common price. The legal price is an administrative fixed price, designed to meet the requirements placed on a just price:

"[...] the prince or magistrate fixes the price at which a particular good is to be sold by considering all the circumstances on which the estimation of goods depends, lest the buyers be deceived or forced to give in to the sellers' whims. The doctors call this price the legal price, as though it were laid down by law. Just as in other circumstances it pertains to the public authorities to promote the common good; likewise, in business, they should prevent fraud and the exploitation of the poor." (Lessius, De lustitia, liber 2, caput XXI., dubitatio 2, [7]).

A common price, on the other hand, is being determined by the supply and demand in a competitive market, usually referred to as common market by late scholastics:

"In the other case, the price is imposed by the common estimation of knowledgeable people. Hence, some call it the common price. Others speak about the natural price, as though it were constituted by natural prudence. It applies to those goods that have not received a price by the public authorities. From Dig. 35, 2, 63, it is obvious that this 
price is just. There it states that the prices of goods are defined neither by affection nor by private advantage but rather

in common. The reason thereof is that private judgment is fallible and easily perverted by love of gain, whereas a common judgment is less subject to error. Because this rule is the most reliable guideline available, we should observe it. The common estimation, then, is realized by taking into account all the circumstances mentioned above." (Lessius, De lustitia, liber 2, caput XXI., dubitatio 2, [9]).

Both the legal price (as long as it is determined with respect to the factors determining a just price) and the common price are considered a just price. However, the common price, as apparent from the passage quoted, is being praised by Lessius for its subjective-free determination. This is an important point because the common evaluation is, beyond any doubt, based on subjective preferences and valuations of the market participants and, in spite of that, the common valuation is objective, in a specific sense of the word, because the common price - actually, a competitive price, as a present-day economist would say - is not being determined by any particular individual. Using the jargon of modern economics, the characteristic feature of the common market is that all participants are price-takers, rather than price-makers. But the term "price-taker" must be used carefully because the common market was probably perceived by the late scholastics as a free-entry market rather than a market with everyone being a price-taker in the strictly perfect-competitive meaning of the word (Chafuen, 2003, p. 83). However, a market participant in a free-entry market must always take other market participants (actual or potential) into account. In such a market, there is a certain room for maneuvering in the price making but this room is very limited relatively to a monopolistic market. Dempsey characterizes a common market as follows:

"A common market is one from which monopoly is absent; from which is excluded, as we shall see, 'every machination and effort of merchants by which they bring it about that they alone either have the sale of something or sell at a certain price' [Dempsey quotes Lessius, De lustitia, liber 2, caput XXI., dubitatio 21, [144]] and in which price is based 'on the common valuation, made in good faith, entered upon without conspiracy or trickery, in view of the supply or scarcity of goods, buyers and sellers, and other circumstances.' [Dempsey quotes Molina, De lustitia et lure, tomus secundus, disputatio 348, [3]]" (Dempsey, 1943, p. 150).

Let us emphasize an important insight, at this point: from the above said, it does not follow that a just price and a common price (competitive price) is one and the same thing. That would be an erroneous inference. The above said just implies that a just price may be represented by a common price (competitive price). Representation is not identity. The importance of this point will become clearer later on. 
Since a just price may be represented by a common price (competitive price), it follows that the just price must undergo fluctuations, as any market price. Schumpeter provides an interesting insight at this point:

"[...] the late scholastics identified their just price not, as Aristotle and also Duns Scotus seem to have done, with normal competitive price but with any competitive price (communis estimatio fori or pretium currens). Wherever such a price existed, it was 'just' to pay and to accept it, whatever the consequences might be for the trading parties: if merchants, paying and accepting market prices, made gains, this was all right, and if they suffered losses, this was bad luck or else a penalty for incompetence [...]" (Schumpeter, 1954, pp. 98-99).

Unfortunately, Schumpeter mixes up identification with representation that I mentioned above. However, irrespective of that, if Schumpeter is right about the rest of his assertion, it means that the late scholastics did not consider just only long-run (normal) competitive price but even any short-run (current) competitive price. The consequence is substantial. Gains resulting from high competitive prices in times of scarcity are licit. If the just price were represented by the normal competitive price, gains coming from higher-than-normal prices would have to be regarded illicit because a higher-than-normal price would not represent a just price. Of course, provided the difference would not be that tiny for the competitive price stay within the interval of just price $^{2}$. The late scholastics provided a very detailed analysis of the factors which determine the common price (competitive price), in other words, they identified possible causes of price fluctuations:

"Some of these circumstances relate to the commodities themselves: their scarcity or abundance, the common need for them and their subjective utility. Next, there are circumstances pertaining to the seller: his labor, the expenses, the risks, and the damages he incurs in obtaining, transporting, and storing the goods. Furthermore, the mode of selling plays a role, namely whether the commodities are offered spontaneously or sold on demand.

A final factor concerns the buyers, whether they are few or many, and whether there is lack or abundance of money." (Lessius, De lustitia, liber 2, caput XXI., dubitatio 2, [8]).

Scarcity/abundance determines the position of the supply curve, common need and subjective utility determine the position of the market demand curve and individual demand curve, respectively. Labor, expenses, risks etc. are factors affecting the position the supply curve, number of buyers affect the market demand and lack/abundance of money affects both the market and individual demand. Schumpeter concludes that the late scholastics

\footnotetext{
${ }^{2}$ Unlike a legal price, a common price (competitive price) represents the just price not by a single value but by an interval of values. This fact is given by many factors which cause that a particular price in a particular exchange can deviate from the competitive price within a tolerance interval. (see Lessius, De lustitia, liber 2, caput XXI., dubitatio 2, [10], [11]). These factors are being discussed below.
} 
"listed all the price-determining factors [...] though they failed to integrate them into a full-fledged theory of demand and supply. But the elements for such a theory were all there and the technical apparatus of schedules and of marginal concepts that developed during the nineteenth century is really all that had to be added to them." (Schumpeter, 1954, p. 98)

Casey (2010) points out, though, that there is an opinion among historians of economic thought that even the basics of the theory of marginal utility may be present in works of late scholastics ${ }^{3}$.

Except for the factors determining the competitive price, there was another object of interest for the late scholastics in this regard, and it was the factors determining a morally allowed deviation of a price from that which the good in question "would actually be worth and sold for in other circumstances." (Lessius, De lustitia, liber 2, caput XXI., dubitatio 4). According to Lessius, a good can be sold for a higher price than that which a good "would actually be worth and sold for in other circumstances", in following cases: 1) "merchants are allowed to demand a little higher price than people who are not selling by virtue of office, but just occasionally" [24]; 2) "potential profits foregone, and damages incurred as a consequence of the alienation of the good" and "a seller is allowed to take into account his affections toward the good and the pleasure he takes in it, all of which he is deprived through selling" [26]; 3) "the labor and expenses you have incurred in obtaining, transporting, and storing the goods" [29]; 4) "[o]n the grounds of an abundance of buyers and money but a shortage of goods" [30]; 5) "if you sell it only to do the buyer a favor and if otherwise you would not have sold your good" [31]; 6) "it may happen at auctions that sometimes the common price is exceeded because the buyers are bidding against each other" [33]; 7) "a seller [...] is allowed to sell dearer if the buyer is held to donate a surplus" [37]. And again, a good can be bought for a lower price than that which a good "is worth out of itself", in following cases: a) "the good is of little use to the buyer and is bought to do the seller a favor" [32]; b) "on the grounds of the mode of selling: at a public auction, for instance, or when buyers are solicited to buy" [33]; c) "if there are plenty of goods available and fewer buyers present, as is usually the case at the closing of the fair, particularly when a shortage of money comes on top of this" [36]; d) "A good can be bought cheaper than the common price also on the grounds of donation. For a seller may be held to condone an insufficiently high payment" [37]; e) "[] $f$ you buy plenty of goods at once, you are allowed to buy at a cheaper price than if you had bought only a small amount of goods" [38]. There are two important points to make here, though. First, the phrase "a price which a good 'would actually be worth and sold for in other circumstances"' is used by Lessius in two meanings. In one sense, the phrase refers to the value of the good itself (whatever that means) which is applicable to the most of the cases, except for the cases 4), 6), b), c). The reason is that these excepted cases refer to markets with several buyers and/or sellers and, as

\footnotetext{
${ }^{3}$ Casey mentions Mark Blaug's assertion on this, as made in his Economic Theory in Retrospect. Actually, Casey quotes Economic Thought in Retrospect, at this place (note 22), but that's probably just an accidental mistake.
} 
a result, they are not applicable to isolated exchanges with a non-existing common price where the buyer and seller need to decide about the just price from scratch. In the other sense, the phrase refers to common or competitive price which will usually not be identical to the value of the good itself (whatever that means) but it will change as a result of changing number of buyers and sellers and scarcity/abundance of the good etc. and since the market participants are price-takers (in the sense explained above), they do not need to worry about taking into account all the factors determining the just price (as they would have to in an isolated exchange), they simply take the prevailing common price as the base of their decision making, as Lessius himself confirms in his comment to point 1 ):

"It is to be remarked, however, that this legal ground does not entail the permission to sell dearer than the legal or common price. In the determination of the price, the office of doing business has already been taken account of." (Lessius, De lustitia, liber 2, caput XXI., dubitatio 4, [24]).

Similarly, in his comment to point 3):

"This is to be understood, however, for goods that did not yet have their price determined,

for the first time a good is priced, the seller can take into account extraordinary expenses. [...] Another matter altogether is the case in which the goods have already received a price for which they are sold in different places because one is obliged either to sell at the current price or to retain his goods." (Lessius, De lustitia, liber 2, caput XXI., dubitatio 4, [29]).

Apparently, then, factors which are allowed and licit to be taken into account when deciding about the price in an isolated exchange are not allowed and licit to be taken into account when there is a market with an existing common (competitive) price. The second important point is that there is a rule governing each process of determination of a just price. It can be called "golden rule of just price" and it says that

"The title by which one receives a price for something from another must be resident in the seller [...]" (Dempsey, 1943, p. 139)

The reason is that if the title is resident in the buyer, a seller who would use this title to receive a higher price would be selling the buyer's title to the buyer, that is the seller would be selling something which he does not possess. Price discrimination of the $1^{\text {st }}$ degree, for example, violates this rule because the seller is setting different prices to different buyers according to each particular buyer's willingness to pay. A person's willingness to pay reflects this person's need or utility. This is not a title resident in the seller, though, but in the buyer. A usurer like Mr. Lón mentioned at the beginning of this paper who takes a thing in pawn and lends money for interest aims at persons 
who ran out of other possibilities and this fact forces them to accept any conditions them will be offered to them. The state of need of the borrower is not a title resident in the usurer, though, but it the borrower. Another example of such a title is an advantage which the buyer can have from the good he wants to buy. If the seller uses this advantage to drive the price up, he is selling something that he does not possess. However, the golden rule of just price is not being violated if a seller valuates a thing above its competitive price or above what it "is worth out of itself" and asks a price which reflects this valuation. The reason is that this valuation above the competitive price is a title resident in the seller. However, it is debatable to what extent this valuation or affection must have an objective, rational cause or whether it can be a purely sentimental affection. Lessius, for himself, does not regard purely sentimental affection as a legitimate cause:

"If a good is estimated more on account of the title affections, these affections have to rest on a just reason that makes it prudent to estimate the good so much. As is the case, for example, with a very unique gem or an ancient statue. Now what to do if the affections do not rest on reason, and yet you do estimate the good to be as valuable as the price you demand for it on the basis of your affections? For example, you estimate a house worth 1,000 guilders at 2,000, because it is a family heirloom. Some admit of it, given that anybody is allowed to estimate the inconveniences he suffers. However, I do absolutely not approve of these practices because affections that lack reason need to be corrected. Such affections should not be bought off or made up for by a towering high price." (Lessius, De lustitia, liber 2, caput XXI., dubitatio 4, [27]).

What has been presented on the previous pages has still not settled several severe objections to the concept of a just price and to scholastic economics as such:

\section{Objection 1}

Commutative justice requires equality of exchange as concerns the value of the thing. On the one hand, the scholastics accept the idea that utility is subjective which implies that it cannot be compared inter-personally. On the other hand, the very concepts of commutative justice and just price require the value to be objectively measurable and inherent to the thing. However, objective measurability excludes subjectivity.

\section{Objection 2}

How can an exchange and a price be labelled as unjust if the exchange has been carried out by both parties voluntarily and the price has been agreed upon by both parties without fraud and coercion? 


\section{Objection 3}

All arguments in favor of a just price may sound plausible as long as the just price is being represented by a competitive price in a free-entry market. But how can a just price be found in an isolated exchange of a unique good?

\section{Objection 4}

There has never been given a satisfactory definition of a just price.

\section{Ontological Foundation of a Just Price}

Realistic philosophy states (and provides a proof) that universals (universalia) - that is general terms such as "man", "term", "five" - have their respective equivalents in reality, i. e. universals are not just semantic conventions or labels but they express something real. There are two kinds of real entities, substances (substantia, pl. substantiae) and metaphysical accidents (accidens metaphysicum, pl. accidentia metaphysica). An entity (ens, pl. enta) A substance is an entity (that is something which is or might be in any way) which exists on its own, e. g. "man" or "stone". A metaphysical accident is an entity which only exists on another entity but it cannot exist on its own. E. g. "whiteness" cannot exist in a different way than as being a quality of something else, such as man or chalk. "Five" cannot exist in a different way than being a quantity of something else, such as drops of water or cats. There are 9 categories of metaphysical accidents: quality, quantity, action, passion, location, time, location, relation, habitus. Any entity has its essence (essentia), that is that part of the entity without which the entity would not be what it is. Every substance, as well as every metaphysical accident have their own respective essence. The essence has several layers, though. The author of this paper is an animate being and as such he possesses the essence of an animate being which is called generic essence (essentia generica) because the author belongs to a genus "animate being" on the grounds of his possession of the generic essence of an animate being. At the same time, the author is a man and as such he possesses the essence of a man which is called specific essence (essentia specifica) because the author belongs to a species "man" on the grounds of his possession of the specific essence of a man. At the same time, the author is a unique creature and as such he possesses the individual essence (essentia particularis) as any other entity. Existence (esse) is a fact of being. We distinguish real existence (esse reale) and ideal existence (esse intentionale). For example, Pegasus is an entity with ideal existence. As for real existence, we need to distinguish real extramental existence from real intramental existence. For example, a judgement - a mental act of assigning a predicate to a subject - is an entity which has real intramental existence. While each entity must possess its essence - because without the essence the entity would not be what it is - not every entity must possess real existence. For example, when my dog died it was deprived of its real extramental existence. At the same time, I still can remember it which means that the dog must 
possess some kind of existence. The dog was real and my memories of it are real, so, the dog's existence cannot be ideal, it must be real. It follows that it must be real intramental existence. And vice versa, if a sculptor has an image of a statue, the statue possesses real intramental existence. When the sculptor takes a chisel and a piece of rock and chisels the statue just as he had it in his mind, the statue obtains a real extramental existence. As a matter of fact, the statue has always been in the potentiality (potentia) of the rock. To get actuated, i. e. to obtain real extramental existence, the statue needed an efficient cause or agent (causa efficiens). Until then, the statue only possessed real intramental existence, it only existed in the mind of God, even before it existed in the mind of the sculptor. There are two acts (actus, pl. acta) in the potentiality of essence, i. e. existence and non-existence. In the potentiality of the statue's essence, then, there also are two acts, real extramental existence and real extramental non-existence which is real intramental existence. Essence is potentiality in relation real extramental existence and real extramental existence is an act in relation to essence. In the same way, substance is potentiality in relation to metaphysical accident and metaphysical accident is an act in relation to substance. However, substance is not potentiality in its relation to essence and metaphysical accident is not an act in its relation to its own real extramental existence. The point is that potentiality is potentiality only in its relation to acts. And an act is an act only in its relation to potentiality. It follows that the essence of potentiality is a relation to acts. And the essence of an act is its relation to potentiality. It also follows that a potentiality which would only be related to one act would not be a real potentiality and the act would not be a real act. Any potentiality, as far as it is potentiality, must be related to two acts, at minimum.

An individual's utility resulting from using a thing as grasped by both modern subjective-value economics and scholastics appears to be a metaphysical accident of the individual. An individual is a substance and a particular utility resulting from using a thing is a metaphysical accident of this substance. However, Saint Bernardino of Sienna, as well as Saint Antonino of Florence, distinguishes two kinds of utility. One kind of utility is a subjective utility or desirability as it was just described and Saint Bernardino calls it complacibilitas. The other kind of utility is objective utility or objective value in use which Saint Bernardino calls virtuositas. Chafuen on this:

"In discussing the influence of virtuositas on prices, the Late Scholastics usually referred to the separate utilities that can be derived from similar products. It is for a different virtuositas that good wheat has a higher price than rotten wheat and that a good horse is valued more than one that is old and unproductive." (Chafuen, 2003, p. 81).

This implies that virtuositas is not a metaphysical accident of an individual but it is something on the thing itself. A thing has different abilities to be used or usefulnesses. Each such usefulness is a metaphysical accident of relation of the thing to a particular individual. Such a usefulness is an act which is concealed in the potentiality of 
essence of the thing. To get pulled out of the potentiality and obtain a real extramental existence, a particular usefulness needs an efficient cause. An individual becomes such an efficient cause if he recognizes the particular usefulness as a potential act of the essence of the thing. Thus, virtuositas or value in use, by all accounts, seems to be the potentiality of a thing as far as its usefulness is concerned. In other words, it is a set of all usefulnesses that are in the potentiality of the thing. On the other hand, complacibilitas, by all accounts, seems to be a set of all kinds and levels of desirabilities in the potentiality of an individual, while a particular desirability is an act in relation to complacibilitas. To get pulled out of the potentiality and obtain a real extramental existence, a particular desirability needs an efficient cause. An act of using a thing becomes such an efficient cause. The act of using itself is also an act in relation to a particular aspect of the individual's essence, while this particular aspect of the individual's essence is potentiality in relation to all acts of using something. The act of using something seems to be a metaphysical accident of relation of an individual to a thing. Now, if a thing is being exchanged, the thing is being transferred to the buyer along with the whole of its potentiality, i. e. potentiality of usefulness. So, preserving equality in exchange requires that potentiality of usefulness of the thing which each party is giving, respectively, equals potentiality of usefulness of the thing which each party is receiving, respectively. In case of a monetary exchange, preserving equality in exchange requires that potentiality of usefulness of the thing which the seller is giving equals the received monetary equivalent of this potentiality of usefulness or, in other words, that the potentiality of usefulness of the thing which the buyer is receiving equals the paid monetary equivalent of this potentiality of usefulness.

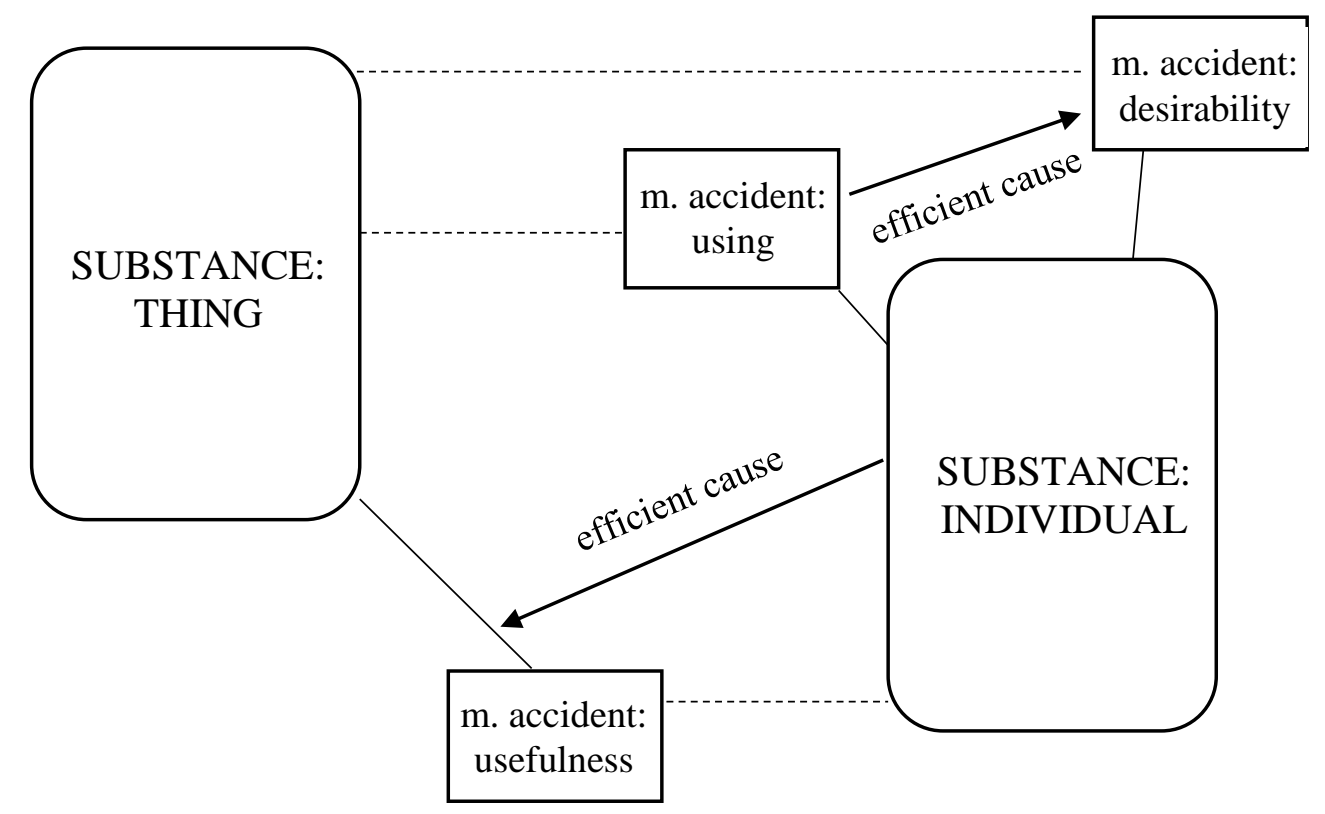

Figure 1. Equality in Exchange: Suggested Ontological Solution 
On the grounds of the above said, Objection 1 can be settled, now:

\section{Reply to Objection 1}

On the one hand, a particular usefulness is not purely subjective because it does not depend on a subjective perception of an individual; it is a metaphysical accident of a thing, not a metaphysical accident of an individual. On the other hand, a particular usefulness is not purely objective, either, because it is a relation to an individual and, as such, its real extramental existence depends on an efficient cause, i. e. an individual. Thus, equality in exchange, required to preserve commutative justice, means equality of potentiality of usefulness which is not a particular usefulness but a set of all usefulnesses concealed in the potentiality of the thing, even though they have not yet been actuated.

\section{Finding the Essence of a Just Price}

As I assert above, I do not regard competitive (common) price and just price as being identical. Rather, I regard a competitive price a representation of a just price. Thus, a just price may be represented by a competitive price under some circumstances but if there is no competitive price, such as in case of an isolated exchange of a unique good such as antiquity, for example, a just price - as long as there is something like this - cannot be identified with a competitive price. In other words, a competitive price may, accidentally, acquire the quality of being just as its metaphysical accident. The essence of this accident is the justness of the just price. So, if examining the competitive market and competitive price carefully, the essence of just price could emerge to us.

Let us assume a barter exchange in three commodities, water, diamonds and gold. Under conditions of an advanced barter exchange, the exchange ratios in all market should be inter-related in such a way that there is no opportunity of a profit from arbitrage. Having an initial amount of water, I sell this amount of water in a competitive water-diamond market and obtain a certain amount of diamonds. Next, I take this amount of diamonds and sell it in a competitive diamond-gold market and obtain a certain amount of gold. Finally, I take this amount of gold and sell it in a competitive gold-water market. I will obtain the same amount of water which I had in the beginning. Equivalence in exchange seems to be preserved and commutative justice seems to be complied with. The point appears to be that when I sell a certain amount of a good and then buy it back for the same price I paid before, I should obtain the same amount. As a matter of fact, this is exactly what characterizes a competitive market. Of course, the price keeps fluctuating, and so I can never be sure that the price will not change within the time span between my selling and my buying back, but, provided the price fluctuates continuously and the market is orderly, the initial and final price will be relatively close to each other (in dependence of the length of the time span, of course). Let us assume a single barter exchange of bread for shoes. If I give 
a shoemaker a loaf of bread for a pair of shoes, the equivalence in exchange will only be preserved if another shoemaker who happens to be buying shoes gives me a loaf a bread when I offer him a pair of shoes. If we generalize this principle to finding a just price, we should ask the following question: how much would I charge anybody for a pair of shoes if I were selling it? At this point, a definition of a just price can be suggested: A just price is such a price which I would accept ex ante if I did not know whether I will be selling the particular thing in the particular exchange for this price or whether I will be buying it for this price. My estimated just price will probably be expressed as an interval, rather than an exact value. But, the other party of the particular exchange will carry out a similar consideration. And he will also estimate his just price as an interval. Now, if my interval and his interval will overlap, at least partially, the just price can be said to have been found. So, it seems that a just price can be defined as follows: A just price is such a price which is being found by two parties of a particular exchange where each party suggests such a price which he would accept ex ante if he did not know whether he will be selling the particular thing in this exchange for this price or whether he will be buying it for this price.

Following the ontological solution of a just price suggested in the previous section, there is a following problem. If an individual does not recognize a particular usefulness in the potentiality of a thing, there will be no efficient cause to pull this particular usefulness out of the potentiality of the thing, i. e. to actuate this particular usefulness, and thus this particular usefulness stays concealed in the potentiality of the thing. Which particular usefulnesses an individual can recognize in the potentiality of a thing will determine his desirability or subjective utility resulting from the thing to him. A question arises: if I am a buyer who wants to buy a thing about which I have recognized a particular usefulness which, by all accounts, the seller has not recognized yet, should I take this particular usefulness into account when I estimate the just price for this thing? My subjective utility or desirability from this thing will be relatively high, no doubt. It is not a product of my subjective tastes and sentimental affections but a product of my recognizing of a particular metaphysical accident concealed in the potentiality of the thing itself which, as I may assume, would most probably increase subjective utility or desirability to the seller, too, if he knew about this particular usefulness. As concerns the "golden rule of just price", we may ask the question whether this title is resident in the seller or in the buyer. On the one hand, the special knowledge is a title resident in the buyer. On the other hand, the knowledge concerns a particular usefulness which rests in the potentiality of the thing itself. But, this thing is still in possession of the seller along with the whole of its potentiality of usefulness. Let us apply the definition of the just price that has been found above: if I, the buyer, were on the side of the seller in this exchange and if I had this special information about the particular usefulness of the thing, then, I would take this particular usefulness as my title into account when suggesting the just price. Since the particular usefulness in a metaphysical accident concealed in the potentiality of the thing itself and, on the grounds of this, anyone who can recognize this can become an efficient cause which pulls this particular usefulness out of the potentiality of the thing, 
I assert that this is a title resident in the seller and, as such, should be taken into account by the buyer when he estimates the just price.

At this point, the remaining objections to the concept of a just price can be settled.

\section{Reply to Objection 2}

1) The buyer does not pay a higher-than-just price voluntarily. If this were the case, the buyer would choose to pay a higher-than-just price even in that case when he could choose to pay a just price.

2) The objection could be developed by an argument that the buyer will always prefer a lower price to a higher price and, as a result, it can be said about any non-zero price that the buyer does not pay it voluntarily. To this I say: if the buyer has an opportunity to pay a lower-than-just price and uses this opportunity, then, the buyer does not suffer injustice (which is always involuntary) but does injustice (which is always voluntary). This implies that, as opposed to the subjective-value-theory based definition of a voluntary exchange, an exchange in which the buyer pays a higherthan-just price or the seller receives a lower-than-just price is not a voluntary exchange.

\section{A proof:}

An exchange in which one party does not act voluntarily is not a voluntary exchange; an exchange in which one party suffers an unjust price is an exchange in which one party does not act voluntarily; ergo: an exchange in which one party suffers an unjust price is not a voluntary exchange. Ad major 1: any exchange in which one party or either party does not act voluntarily is not a voluntary exchange; an exchange in which one party does not act voluntarily is an exchange in which one party or either party does not act voluntarily; ergo: an exchange in which one party does not act voluntarily is not a voluntary exchange. Ad major 2: only that exchange in which both parties act voluntarily is a voluntary exchange; this exclusive judgement is equivalent to: any exchange in which one party or either party does not act voluntarily is not a voluntary exchange. Ad minor 1: who suffers unjust in an exchange does not act voluntarily; who suffers an unjust price suffers unjust in an exchange; ergo: who suffers an unjust price does not act voluntarily. Ad minor 2: who suffers unjust in a given relationship does not act voluntarily; who suffers unjust in an exchange suffers unjust in a given relationship; ergo: who suffers unjust in an exchange does not act voluntarily. Ad minor 3: who suffers an unjust price is the one who does not act voluntarily; since the predicate is being assigned to the subject truthfully, a following judgement must also be true: an exchange in which one is that who suffers an unjust price is an exchange in which one is that who does not act voluntarily.

\footnotetext{
${ }^{4}$ This premise is being inferred by Saint Thomas (Summa, II-II, questio 59, articulus 3, commentarii).
} 
3) The objection could be developed by an argument that a buyer who pays a lowerthan-just price would wish to pay a still lower price if he were allowed to. So, even though he pays a lower-than-just price, he would choose to pay a still lower price if he could which implies that he does not pay the current price voluntarily. In relation to higher prices than the current price he pays, his decision to pay the current lowerthan-just price is voluntary. But, in relation to lower than the current price he pays, his decision to pay the current lower-than-just price is involuntary. As a result, the term "voluntary" is completely relative. Thus, the only meaningful criterion of voluntariness is a manifest consent under absence of coercion and fraud. To this I say: if someone is about to sell a thing to me for a price which he considers higher than just, it is unjust. As far as it an exchange is unjust, the manifest consent is not voluntary. As a result, this involuntariness is not relative because the identity thereof as involuntariness is not given by its relation to this or that price but by the presence of injustice which consists in the intentional act of setting the price at a higher-thanjust level.

\section{Reply to Objection 3}

That a just price is often not easy to find or determine exactly does not imply that the concept of a just price is meaningless. The traffic regulations know a term "safe distance". However, the safe distance changes depending on the speed of the vehicle, condition of the roadway, weather conditions, the driver's experience, the driver's reactive agility, condition of the brakes, condition of the tires, mass of the vehicle etc. Apparently, it is impossible to determine the value of the safe distance in a particular situation precisely. Does this mean that a driver should give up finding and keeping a safe distance when he drives his car on a freeway? Obviously not. Besides, a question of justice in exchange should be separated from a question of discovering a value of a just price in a particular exchange. It cannot be inferred from the presence of practical difficulties in discovering a value of a just price in a particular exchange that nothing like equality in exchange exists, as much as it cannot be inferred from the presence of practical difficulties in discovering a precise value of a safe distance that nothing like a safe distance exists.

\section{Reply to Objection 4}

A just price is such a price which is being found by two parties of a particular exchange where each party suggests such a price which he would accept ex ante if he did not know whether he will be selling the particular thing in this exchange for this price or whether he will be buying it for this price. 


\section{Conclusion}

This paper presents the main points made by scholastic teachers on the subject matter of a just price. After a detailed exposition of the scholastic theory of value, price and commutative justice, I have identified four subjective-value-based objections that need to be settled if the concept of a just price is ever to be rehabilitated. The first objection points out the apparent self-contradictory character of the concept which, on the one hand, asserts a subjective nature of utility and, on the other hand, on the grounds of preserving the equality in exchange, requires equality of value given and value obtained. The second objection questions the apparent injustice in an exchange which both parties have entered voluntarily, without any fraud and coercion. The third objection draws attention to the fact that the late scholastics identify, basically, a just price with a competitive price, which makes the concept of a just price in a condition of an isolated exchange of a unique good very dubious. The fourth objection reproaches the advocates of the concept of a just price that they have never provided a satisfactory definition of a just price.

I have tried to settle the first objection by identifying the ontological status of the objective value. Leaning on a distinction of an objective value in use (virtuositas) and subjective desirability (complacibilitas) made by Saint Bernardino of Sienna and Saint Antonino of Florence, I assert that while complacibilitas is a potentiality of subjective desirability resting in an individual, virtuositas is a potentiality of usefulness resting in a thing. Each particular usefulness is a metaphysical accident of relation of the thing to a particular individual. Such a usefulness is an act which is concealed in the potentiality of essence of the thing. On the other hand, complacibilitas, by all accounts, seems to be a set of all kinds and levels of desirabilities in the potentiality of an individual, while a particular desirability is an act in relation to complacibilitas. With respect to a just price, I draw a following conclusion, then: On the one hand, a particular usefulness is not purely subjective because it does not depend on a subjective perception of an individual; it is a metaphysical accident of a thing, not a metaphysical accident of an individual. On the other hand, a particular usefulness is not purely objective, either, because it is a relation to an individual and, as such, its real extramental existence depends on an efficient cause, i. e. an individual. Thus, equality in exchange, required to preserve commutative justice, means equality of potentiality of usefulness which is not a particular usefulness but a set of all usefulnesses concealed in the potentiality of the thing, even though they have not yet been actuated.

As concerns the second objection, I have provided a logical proof for the assertion that an exchange in which one party suffers an unjust price is not a voluntary exchange; one of the premises used in this proof, namely "who suffers unjust in a given relationship does not act voluntarily", was inferred by Saint Thomas. On the grounds of this, I have tried to challenge the subjective-value-based definition of a voluntary exchange as an exchange entered without coercion and fraud. I have showed that an unjust exchange cannot be a voluntary exchange. 
As regards the third and fourth objection, I have suggested a definition of a just price which is applicable to any exchange, whether a competitive price exists or not. Even though a competitive price may, accidentally, acquire the quality of being just as its metaphysical accident, still, the essence of this accident is the justness of the just price. I contend that a just price as estimated by either party in an exchange may be defined: a just price is such a price which I would accept ex ante if I did not know whether I will be selling the particular thing in the particular exchange for this price or whether I will be buying it for this price. This estimated just price will probably be expressed as an interval, rather than an exact value. At the same time, the other party of the particular exchange will carry out a similar consideration and estimate the just price by means of an interval. As long as the intervals of both parties overlap, at least partially, the just price can be said to have been found. So, I suggest a following definition: A just price is such a price which is being found by two parties of a particular exchange where each party suggests such a price which he would accept ex ante if he did not know whether he will be selling the particular thing in this exchange for this price or whether he will be buying it for this price.

\section{References:}

CASEY, G. N. (2010). The Major Contributions of the Scholastics to Economics. [online]. Available at: https://mises.org/library/major-contributions-scholastics-economics

CHAFUEN, A. A. (2003). Faith and Liberty: The Economics of the Late Scholastics. Lexington Books, 2003. ISBN 0-7391-0540-X.

DEMPSEY, B. W. (1943). Interest and Usury. Washington, D. C.: American Council of Public Affairs, 1943.

LESSIUS, L. (1605). De lustitia et lure. Liber 2. Caput XXI. (De Emptione et Venditione). In DECOCK, W. (2007). On Buying and Selling. Journal of Markets \& Morality. Fall 2007, Vol. 10, No. 2, pp. 433-516.

SCHUMPETER, J. A. (1954). History of Economic Analysis. London: Allen \& Unwin, 1982. ISBN 0043303765.

THOMAS AQUINAS. Sententia libri ethicorum. Liber $V$. Available at: http://dhspriory.org/thomas/Ethics.htm

THOMAS AQUINAS. Summa Theologiae. Secunda Secundae Partis. Available at: http://www.ccel.org/ccel/aquinas/summa.i.html

ZÚÑIGA, G. L. (2010). Scholastic Economics: Thomistic Value Theory. Religion \& Liberty. July 20, 2010, Vol. 7, No. 4. Available at: http://acton.org/pub/religion-liberty/volume-7-number-4 